\title{
ANALYSIS OF SOCIAL RESILIENCE TO THE NOVEL CORONAVIRUS (COVID-19) IN ALGERIA
}

\author{
Yahyaoui Habibi, Sami Guellouh, Abdelwahhab Filali, Razika Berchiche
}

\begin{abstract}
Summary
This paper is an attempt to understand and overcome the peculiarity of the novel Coronavirus (Covid-19), described as a pandemic by the World Health Organization. Covid-19 is spreading around the world, and particularly in Algeria, which announced the identification of the first case on the 26 February 2020. The number of confirmed cases is increasing day by day. Currently, we experience the spread of the word "resilience" in most diverse research areas and policy fields of modern society. Social resilience is the capacity of a social entity to proactively adapt to and recover from disturbances that are perceived within the social entity to fall outside the range of normal; this includes expected and unexpected disturbances. The main objective of this study is to contribute towards connecting the socio-economic vectors of this pandemic, and to integrate them into the GIS (Geographic Information System), in order to analyze the level of social resilience in Algeria. The analysis adopted the method known as the Hierarchical multi-criteria analysis (AHP), which defines the relative importance of each characteristics.

The findings of our research show that the factors of high unemployment and housing occupancy rates, high population density and the share of citizens aged over 60 directly influence the reduction in the level of social resilience to the novel coronavirus.
\end{abstract}

Keywords

$\mathrm{WHO} \bullet \mathrm{GIS} \bullet$ coronavirus $\bullet$ Algeria $\bullet$ COVID-19 $\bullet$ social resilience

\section{Introduction}

Since December 2019, a new pandemic of Coronavirus (COVID-19) is spreading worldwide. The virus has made millions of people sick, challenged the largest health systems, and led to restrictions on almost all activities and the closure of major cities. As is the case, Coronavirus is defined as a large group of viruses that cause serious respiratory illnesses; moreover, the new strain of Coronavirus has been identified as the cause of the first case detected in Wuhan, China. The impact of this pandemic has reached Algeria despite the measures taken by the government, and the number of confirmed cases remains constantly on the rise. 
The overall objective of this work is to highlight the level of resilience in each wilaya of the whole of the national territory; thus taking into account the connection of a set of factors, namely: the density of the population, the unemployment rate, the occupancy rate of the accommodation, and the share of the age group above 60 years in the population. Hence, the choice of research method had been determined by the nature of the proposed problem and the objective of the study; conceptually, it is based on a multicriteria decision support method called the AHP (hierarchical multi-criteria analysis) [Saaty 1980], where we used a parametric indexed approach where each parameter is indeed a numerical index translated by a code used for modeling for prevention purposes. The findings of the present research show that low resilience is synonymous with high unemployment rate, housing occupancy, and finally the share of citizens aged over 60 years.

\section{Geographical location}

Algeria is located in North Africa, with an area of 2.38 million $\mathrm{km}^{2}$. It extends towards the North to South, from the shore of the Mediterranean to the most barren parts of the Sahara, at almost exactly south of the 20th north meridian. It is bordered to the West by Morocco and Western Sahara, to the East by Tunisia and Libya, in the South by Niger, Mali and Mauritania. As an independent republic since 1962, marking a 43 million population in 2019, Algeria is divided administratively into 48 provinces (wilayas), where the capital is Algiers, with other major cities such as: Oran, Annaba, Constantine.

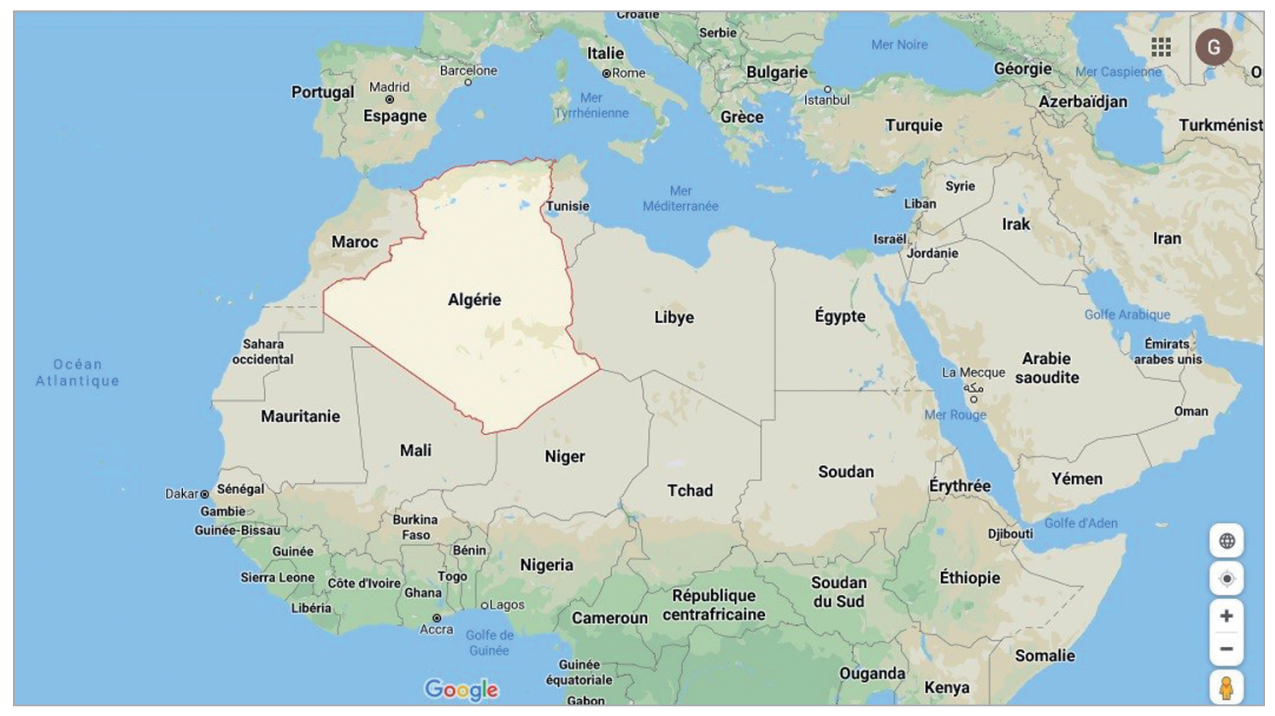

Source: Google Maps

Fig. 1. Geographical location of Algeria 


\section{Study approach}

The concept of resilience has evolved stepwise from its initial emphasis on the general persistence of ecological system functioning in the world that is subject to ongoing change, through an orientation towards coupled social-environmental systems and questions of the adaptation of humans in nature, to its most recent readjustment, in taking up the more critical question of social transformation in the face of global change. We suggest that this particular genealogy is indicative of the underlying principles that constitute the resilience concept, i.e. persistability, adaptability, and transformability [Keck and Sakdapolrak 2013].

As clearly highlighted by previous researches, all definitions of social resilience concern social entities - be they individuals, organizations or communities - and their abilities or capacities to tolerate, absorb, cope with, and adjust to environmental and social threats of various kinds [Keck and Sakdapolrak 2013]. Social resilience to health risks is the inherent ability of a health system to sustain shock or to avoid it. For this to happen, a society may increase its resilience by simultaneously acting towards the preparation, improvisation, emergency plans simulation, and organizational learning. In complex situations that involve social resilience to the novel Coronavirus, this is directly linked to the adoption of containment measures, where the success of the latter is dictated by socioeconomic and demographic factors that constitute the parameters for assessing the level of resilience in each wilaya.

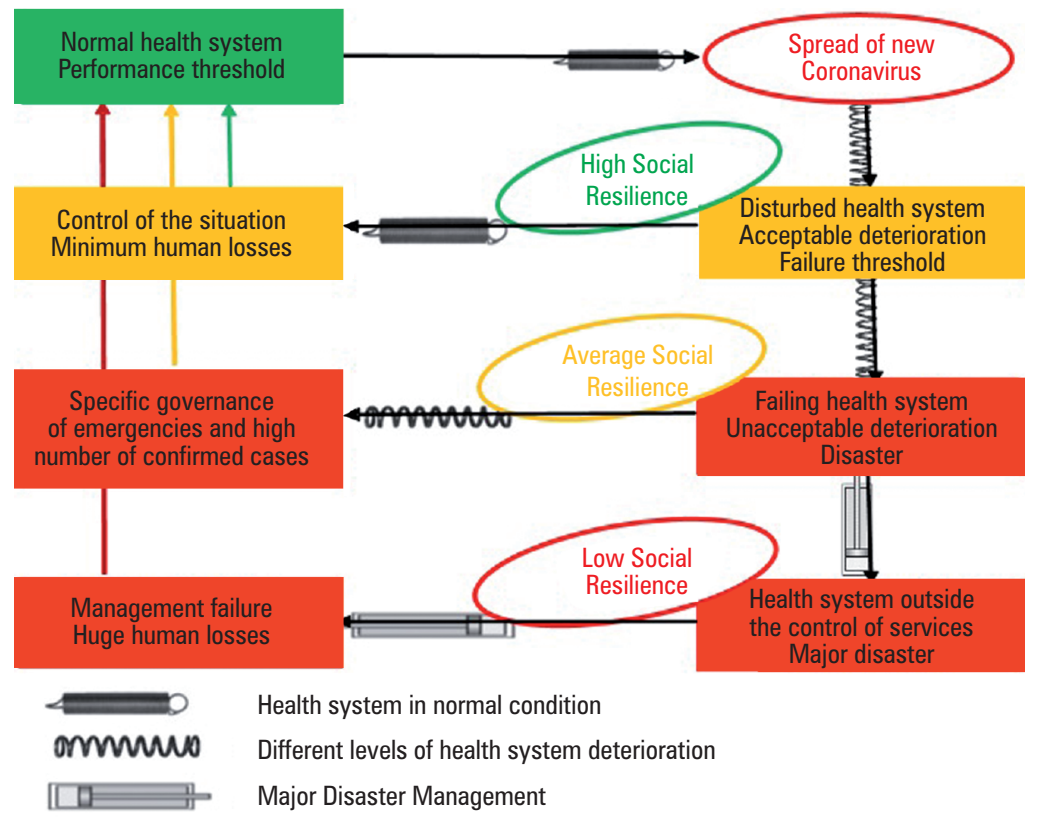

Fig. 2. Social resilience schemes to the spread of Covid-19 


\section{Material and methods}

The present work attempts to shed some light on the level and mapping of social resilience, starting by viewing several thematic maps, which had been previously drawn up - namely the map of the population density, the unemployment rate, the housing occupancy rate, and the share of the age group above 60 years.

\subsection{The population density}

This factor has an important impact on the social resilience of the population, especially in large cities that are highly populated, which contributes to creating conditions conducive to the rapid spread of the virus. In addition, the population density is a specificity of cities in the coastal strip where the concentration of human settlements is responsible for a high level of vulnerability. In the coastal strip, we observe the emergence of the wilaya of Algiers with a population density of 3666 inhabitants per $1 \mathrm{~km}^{2}$.

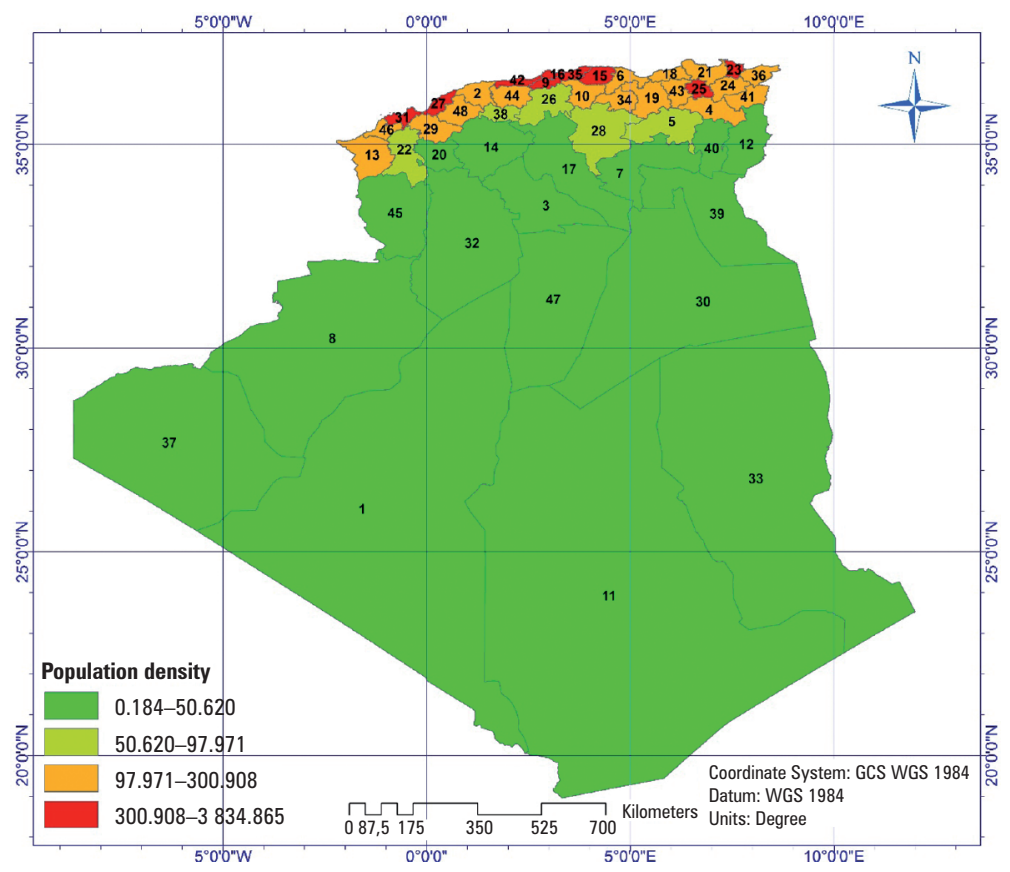

Fig. 3. Map of the population density

As is the case in Algiers, the other wilayas population densities range from 685 inhabitants $/ \mathrm{km}^{2}$ for Oran, 539 inhabitants $/ \mathrm{km}^{2}$ for Boumerdes, to 102 inhabitants $/ \mathrm{km}^{2}$ for El-Tarf, and finally 104.7 inhabitants $/ \mathrm{km}^{2}$ for Tlemcen; indeed, for the Tell and the Steppe the imbalance is more important, marking a density of more than 429 inhabitants/ 
$\mathrm{km}^{2}$ for the wilaya of Constantine, to 39.4 inhabitants $/ \mathrm{km}^{2}$ for Khenchela, to only 6.4 inhabitants $/ \mathrm{km}^{2}$ for the wilaya of El Bayad, and the same case has been observed for the South wilayas where the density varies from 34.4 inhabitants $/ \mathrm{km}^{2}$ for the wilaya of Biskra to less than one inhabitant for the wilayas of Adrar $\left(0.91\right.$ inhabitants $\left./ \mathrm{km}^{2}\right)$, Tamanrasset (0.32 inhabitants $\left./ \mathrm{km}^{2}\right)$, Tindouf (0.31 inhabitants $\left./ \mathrm{km}^{2}\right)$, and Illizi $\left(0.18\right.$ inhabitants $\left./ \mathrm{km}^{2}\right)$.

\subsection{The population age}

According to statements from the World Health Organization, about $80 \%$ of COVID19-related deaths occur in people over the age of 60 . More than $70 \%$ of the Algerian population is young, aged less than 30 years old, which constitutes protection against the most devastating human costs linked to the spread of the pandemic. Nevertheless, almost 2.55 million represent the category of people aged 60 and over in 2020 according to the data from the National Statistics Office (ONS), with a national average of $7.4 \%$.

Bearing in mind that in the present complex situation the United Nations considers "elderly" any person who has reached the threshold of 60 years of age, the ONS highlighted the introduction of a new concept concerning this category, namely "life expectancy in good health", referred to the indicators of "dependence" among this population. In this regard, the ONS declares that $55.3 \%$ of the population in question suffer from chronic pathologies, including more than half of women, while $30 \%$ are "severely compromised" health-wise, with a proportion almost equal in both sexes.

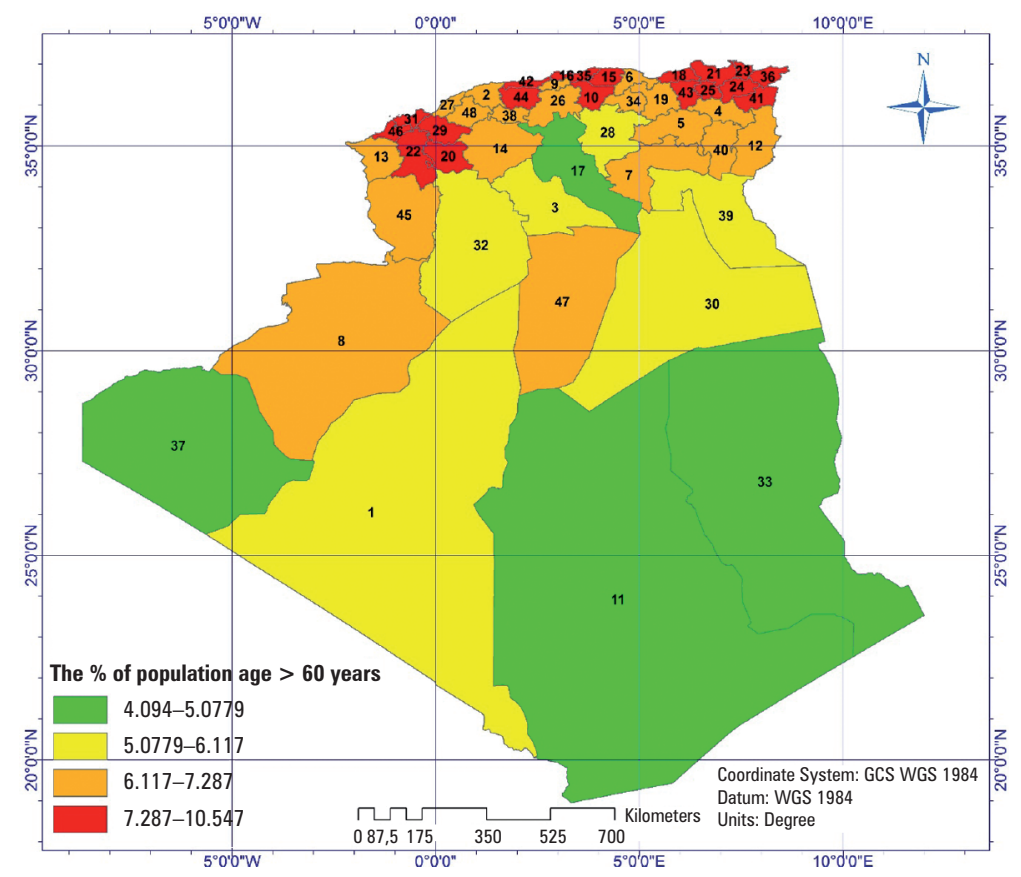

Fig. 4. Map of the population age 


\subsection{The occupancy rate of the accommodation}

Seeking population containment is an essential means of controlling the spread of the Coronavirus. What constitutes an obstacle is the character of Mediterranean and African peoples like ours, where social life is of great importance, and neighbourly relations play a particularly important role, whereas the simplicity of contact protocols between individuals have forged outgoing and expressive personalities, open to others even in adversity. Moreover, an Algerian's relational field is very broad and he maintains it in various ways, as much for socio-cultural reasons as for network strategies, made necessary by the complexity and hostility of the administrative environment. Although neighborhood building and social life have been in sharp decline since the beginning of the twenty-first century, they still remain an existential point of reference.

Another difficulty is how to support containment in the structure of housing in Algeria, which is mainly collective, with an urbanization rate of the population that exceeds $70 \%$ in 2018, and a projection of $85 \%$ for 2050 (extrapolated from the 2008 population census). This translates to the occupancy rate per dwelling (TOL) of 6.4 people per accommodation, reaching 7.4 in the wilaya of Tissemsilt, and 7.3 in those of Médéa and Laghouat. This rate has not changed much since it was 6.1, despite the massive construction programs.

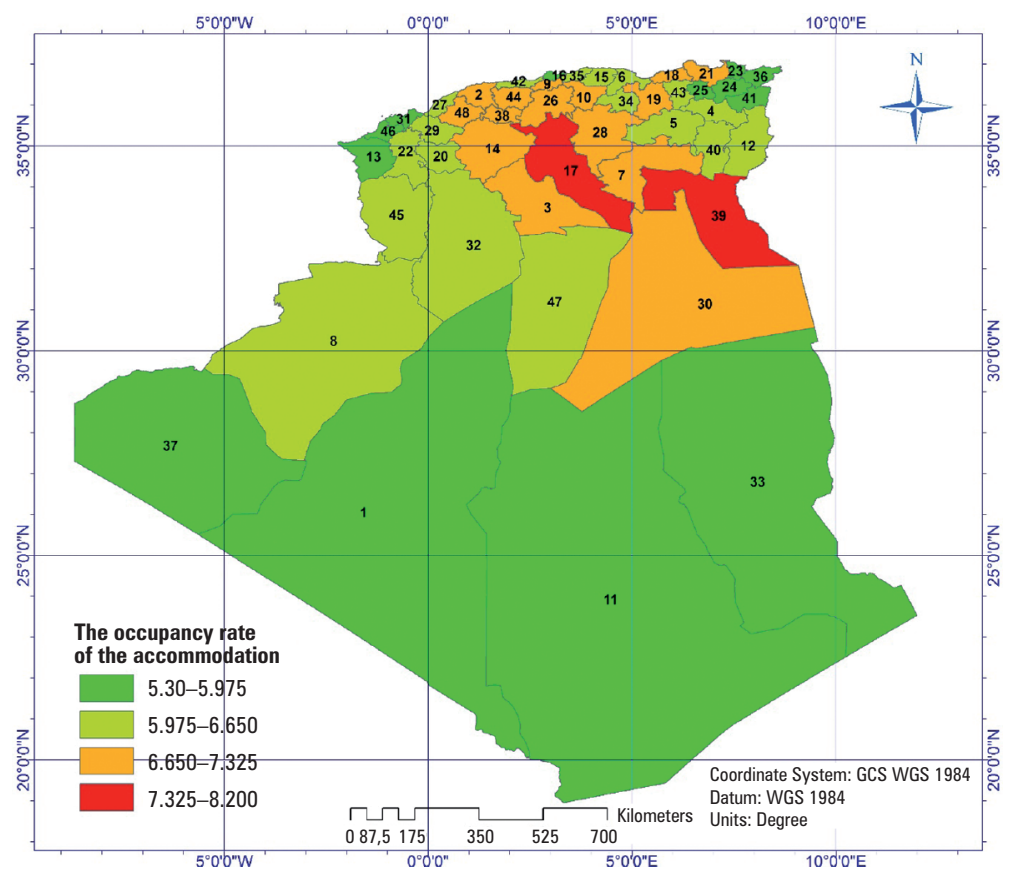

Fig. 5. Map of the occupancy rate of the accommodation 


\subsection{The unemployment rate}

Like elsewhere in the world, Algeria is not immune to unemployment; in fact, this global phenomenon affects too large a share of the working-age population, where the rate of joblessness is high according to age, sex, and level of education, and where the consequences are harmful to the economy.

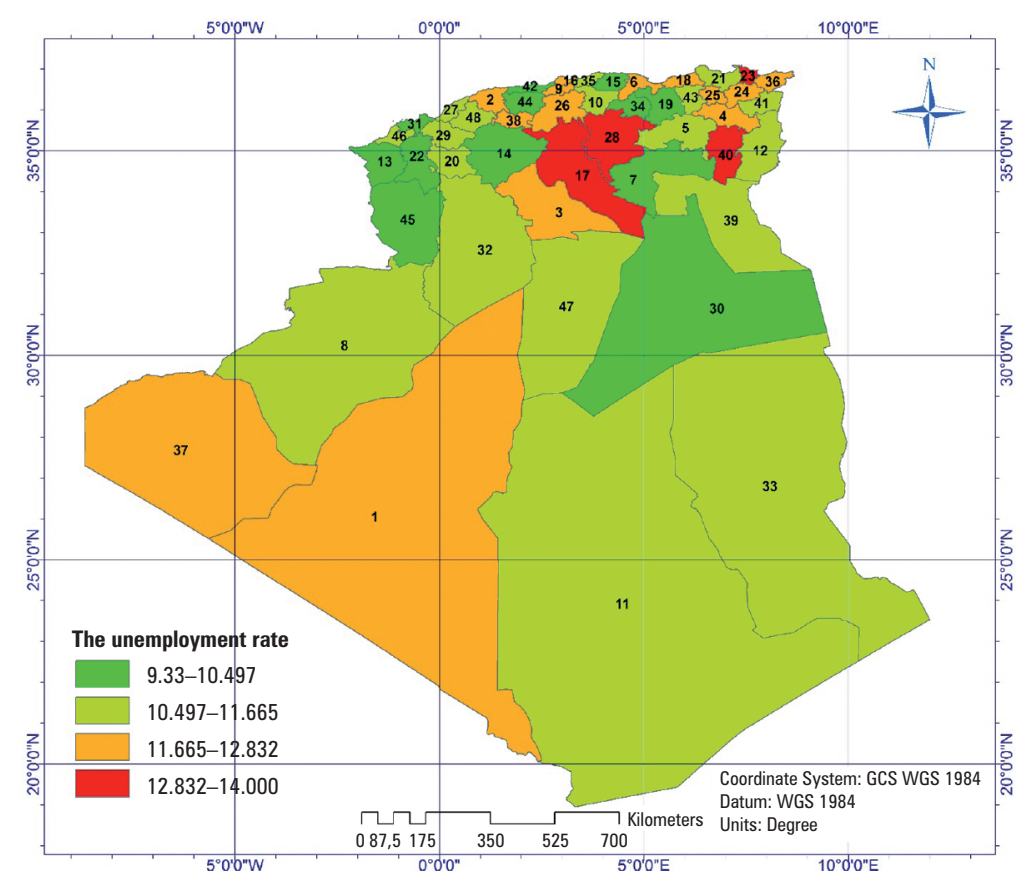

Fig. 6. Map of the unemployment rate

In order to complete this study, the method of Hierarchical multi-criteria analysis (AHP) was adopted for the analysis. The AHP was invented by the mathematician Thomas Saaty [1980], as a multi-criteria analysis method that can be used in the quantification of qualitative characteristics, through their weighting [Ramos et al. 2014]. The AHP process is based on the comparison of different characteristics, two by two, providing a flexible method for setting priorities and rendering them to the various levels of the hierarchy. This allows an assessment of the logical consistency of the opinions used to determine priorities [Barczak et al. 2007]. In this approach, using the structure of a square matrix, the relative importance of one characteristic in relation to another is assessed using an adequate scale [Ramos et al. 2014], and where the sum of scores equals 1 [Griot 2014]. 
Table 1. Pairwise comparison scale

\begin{tabular}{|c|l|l|}
\hline Importance & \multicolumn{1}{|c|}{ Definition } & \multicolumn{1}{c|}{ Explanation } \\
\hline 1 & Equal importance & Two elements contribute equally to the objective \\
\hline 3 & $\begin{array}{l}\text { Moderate } \\
\text { importance }\end{array}$ & $\begin{array}{l}\text { Experience and judgment slightly favour one parameter over } \\
\text { another }\end{array}$ \\
\hline 5 & Strong importance & $\begin{array}{l}\text { Experience and judgment strongly favour one parameter over } \\
\text { another }\end{array}$ \\
\hline 7 & $\begin{array}{l}\text { Very strong } \\
\text { importance }\end{array}$ & $\begin{array}{l}\text { One parameter is favoured very strongly and is considered } \\
\text { superior to another; its dominance is demonstrated in practice }\end{array}$ \\
\hline $2,4,6,8$ & $\begin{array}{l}\text { Extreme } \\
\text { importance }\end{array}$ & $\begin{array}{l}\text { The evidence favouring one parameter as superior to another is } \\
\text { of the highest possible order of affirmation }\end{array}$ \\
\hline
\end{tabular}

Source: Saaty [1980]

The chosen factors (characteristics) interact with each other in a dynamic way. This has allowed us to create the social resilience map. The application of the Arc GIS software and its extensions made the task easier and facilitated adding weights to the various thematic maps.

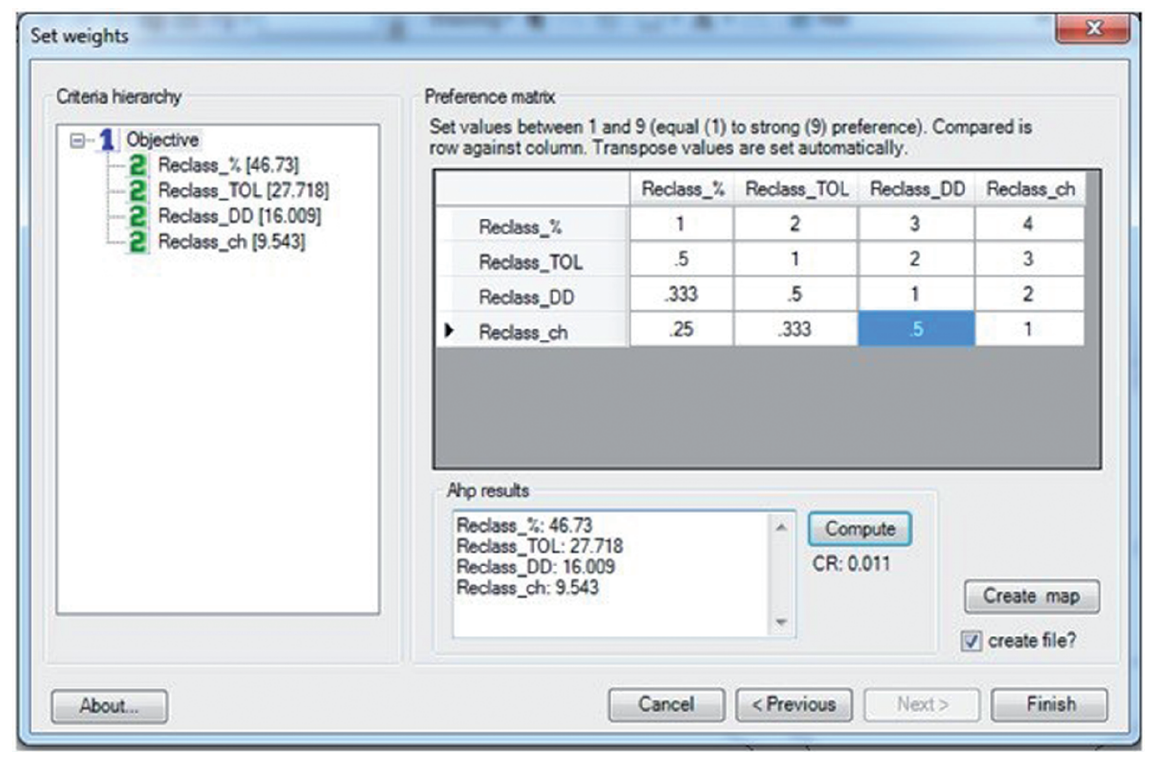

Fig. 7. Comparison matrix under the Arc GIS 


\section{Results and validation}

The combination between the different thematic layers according to the AHP (Hierarchical Analysis Process) led us to the spatialization of social resilience to the novel Coronavirus subdivided by wilayas. The obtained results revealed that the populations in 14 wilayas mark a low social resilience to containment measures; this is linked to high unemployment and housing occupancy rates, high population density, and the number of citizens aged over 60 .

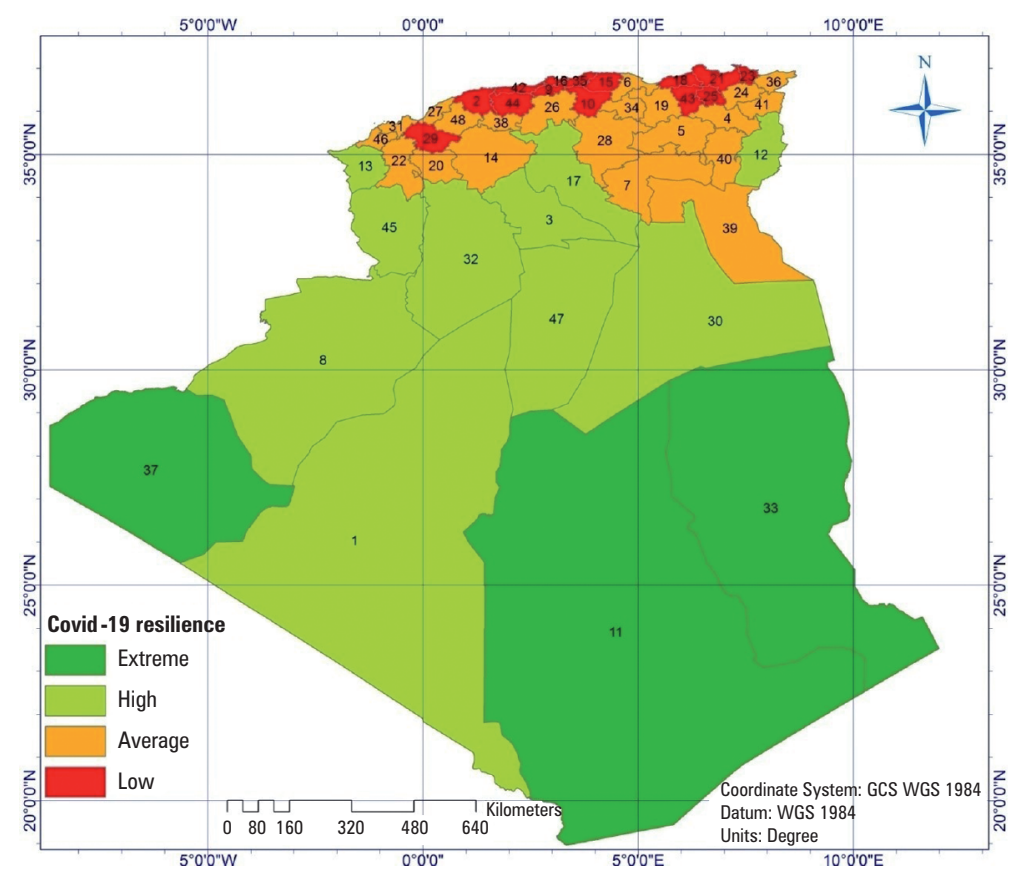

Fig. 8. Covid-19 resilience

The comparison between the results and the current status in terms of the number of confirmed Coronavirus cases declared by the Minister of Health on 15 June 2020 clearly shows the contribution of the approach used in the analysis of social resilience.

\section{Conclusion}

The overall objective of this study is value the importance of the relation to connect the socio-economic vectors of the Coronavirus pandemic and to integrate them into GIS, in order to analyse the level of social resilience in Algeria.

The results of this research work clearly demonstrate the contribution of GIS in the spatialisation of social resilience to the spread of the novel Coronavirus. Indeed, the 
synthesis map provides a spatial zoning that can more at least meet the needs expressed by public authorities as well as by health decision-makers in Algeria. The analysis of the current state of social resilience shows a low social resilience in several wilayas.

The GIS and AHP approach have made it possible to define and better pinpoint the wilayas with low social resilience. This is a real decision-making tool for public health managers to think about improving conditions for hospitalization and crisis management.

The study concluded that the results are significant and meet our research objectives. We have seen the socio-economic vectors to directly influence the reduction in the level of social resilience.

\section{References}

Barczak A., Grivault C. 2007. Système d'Information Géographique pour l'évaluation de la vulnérabilité au risque de ruissellement urbain. Novatech.

Djafri R., Osman M.M., Noor S.R., Shuid S. 2019. Algerian Housing Policies. Asian Journal of Environment - Behaviour Studies, 4 (13), 1-15.

Griot Ch. 2014. Vulnérabilité et transport de matières dangereuses: une méthode d'aide à la décision issue de l'expertise de la Sécurité Civile. Cybergeo. Européen Journal de Géographie, Systèmes, Modélisation, Géostatistiques, document 361.

Habibi Y. 2018. The proximity of city - industrial estate in the town of Batna (North East of Algeria) management of major technological risks through an integrated approach to urban resilience. Anallelle Universităţii din Oradea, Seria Geografie, 1, 19-27.

Keck M., Sakdapolrak P. 2013. What is social resilience? Lessons learned and ways forward. Erdkunde - Archive of Scientific Geography, 67, 1.

Lahmar K. 2019. Unemployment in Algeria. International Journal of Rural Development, Environment and Health Research (IJREH), 3, 1.

Ramos A., Cunha L., Cunha P.P. 2014. Application de la Méthode de l’Analyse Multicritère Hiérarchique à létude des glissements de terrain dans la région littorale du centre du Portugal: Figueira da Foz - Nazaré. Géo-Eco-Trop, 38, 1, 33-44.

Saaty T.L. 1980. The Analytic Hierarchy Process: Planning, Priority Setting, Resources Allocation. McGraw-Hill, London.

Post-doctoral degree Yahyaoui Habibi

Geography and Territory Planning, Natural Hazards and Territory Planning Laboratory

Batna 2 University, Algeria

ORCID: 0000-0002-3942-8675

e-mail: y.habibi@univ-batna2.dz)

Post-doctoral degree Sami Guellouh

Geography and Territory Planning, Natural Hazards and Territory Planning Laboratory

Batna 2 University, Algeria

ORCID: 0000-0002-0051-5771

e-mail: s.guellouh@univ-batna2.dz 
Post-doctoral degree Abdelwahhab Filali

Geography and Territory Planning, Natural Hazards and Territory Planning Laboratory

Batna 2 University, Algeria

ORCID: 0000-0002-6730-969X

e-mal: a.filali@univ-batna2.dz

Post-doctoral degree Razika Berchiche

Geography and Territory Planning, Natural Hazards and Territory Planning Laboratory

Batna 2 University, Algeria

ORCID: 0000-0002-5312-8775

e-mail: berchiche.raz@gmail.com 